\title{
Peculiarities of the juvenile convicts' behaviour in a frustrating situation
}

\author{
O. S. Nedybaliuk, N. Yu. Maksymova \\ Taras Shevchenko National University of Kyiv, Kyiv, Ukraine \\ Corresponding author. E-mail: elena.kiev89@gmail.com \\ Paper received 16.08.18; Accepted for publication 22.08.18.
}

https://doi.org/10.31174/SEND-PP2018-174VI72-13

\begin{abstract}
The article deals with the problem of resocialization of juvenile convicts through the development of their assertive behaviour. The connection between the assertiveness and a certain correlation of the adolescent's reaction to the frustrating situation is proved. The method of detecting the reaction to frustration in adolescents based on the modification of the frustration test by S. Rosenzweig has been developed. The types of behaviour strategies are determined in accordance with the parameters of assertiveness: assertive, non-assertive, aggressive, contradictory, unformed. The results show that the juvenile convicts detect considerably less strategies for assertive behaviour in comparison with the children of school age. The schoolchildren behave aggressively more often than the juvenile convicts do. At the same time, the level of non-assertive behaviour among the schoolchildren is more than three times lower.
\end{abstract}

Keywords: resocialization, juvenile convicts, frustrating situations, assertiveness, adolescents.

Introduction. The main task of the penal system is the resocialization of the convicts. This task is especially important when it comes to juvenile convicts. Many actions on resocialization of juvenile convicts are taken at the Penitentiary Service, but they are not effective enough. One of the reasons for such inefficiency is an inadequate scientific validity of educational effects and the lack of a differential approach to the correction of those personal features that are inherent in a particular convict.

A brief overview of publications on the topic. Researchers $[1,3,4]$ define a range of various problems which the convicts come across especially while preparing for dismissal from the places of their imprisonment. One of them is connected with the need to communicate and establish relationships with certain social groups (family, labor collective, etc.) and other social needs that arise with the entry of a person into a new microenterprise. The authors believe that in order to solve these problems the juvenile offenders need assertive skills in their interaction with the environment. An important component of the resocialization of juvenile convicts is the formation of social skills, in particular the reactions of juvenile convicts to various frustrating situations that may occur in their lives. It gives an opportunity to determine the socio-psychological readiness of the adolescent to release and to prevent recurrence. Timely detection of the tendency to unconstructive reactions of juveniles in frustrating situations is the basis of correction of their behaviour in conditions of educational colonies.

One of the reasons of juvenile convicts' repeated involving in an offence and taking them to the educational colonies is the lack of competent behaviour in a frustrating situation and inability to find a way out in conflict situations [4].

A clear personal position, understanding and awareness of the risks of the actions performed under the influence of others, the ability to make adequate socially positive decisions and to be responsible for the consequences of their actions can be a guarantee of positive resocialization, preventing repeated crimes [1]. The availability of assertive skills in behaviour is very important in this issue. Determining the degree of assertive behaviour formation in convicts is an important part for dismissal preparation.
The concept of "assertiveness" as a component of the interpersonal interaction theory was proposed and developed by the American psychologist A. Solter. Assertiveness was studied by the author as a certain way of personal behaviour, accompanied by a sense of respect for his own personality and emotional and valuable relation to other people.

Researchers consider assertiveness to be a harmonious combination of personal human traits, reflected in the form of specific ideological views and positive orientation, which reveal in knowledge of human nature, in the skills and abilities of effective interaction [2]. Assertiveness is realized through the ability to express one's thoughts and feelings, to realize desires in such a way that it is neither a threat nor punishment, nor humiliation of another person [3]. We consider assertiveness to be a person's awareness of his right to achieve what he or she desires; the ability to express their thoughts and feelings directly - both positive and negative, but in a way not to violate the rights of other people. Assertiveness is precisely the condition for constructive behaviour in frustrating situations.

The aim of our study was to determine the particular behaviour of juvenile convicts in a frustrating situation. The study was conducted in 2015-2016. It involved 30 juvenile convicts of the Priluky Educational Colony of the State Penitentiary Service of Ukraine in the Chernihiv region. In order to compare the obtained data on juvenile convicts with the indicators of the normative group, the pupils of secondary schools (120 persons) of the same age were taken as the participants of the study.

Research methods. To determine the behaviour of the studied participants in frustrating situations, the method of S. Rosenzweig was used [5].

Results and their discussion. As a result of a trial study conducted in 2015, it turned out that the method of S. Rosenzweig does not entirely correspond to our research goal. Some of the pictures according to their content no longer meet the interests and needs of modern teenagers, and therefore the situations that were depicted on them can not be frustrating. That's why the details of the pictures were changed in order to bring situations closer to the real events, relevant to the age of the juvenile convicts, which they may come across in the society. Moreover, the content and details on 2 of 10 situations, 
presented in the original source, were changed in order to conduct our study. The number of pictures was reduced in accordance with the research tasks in order to shorten the time spent on its carrying out.
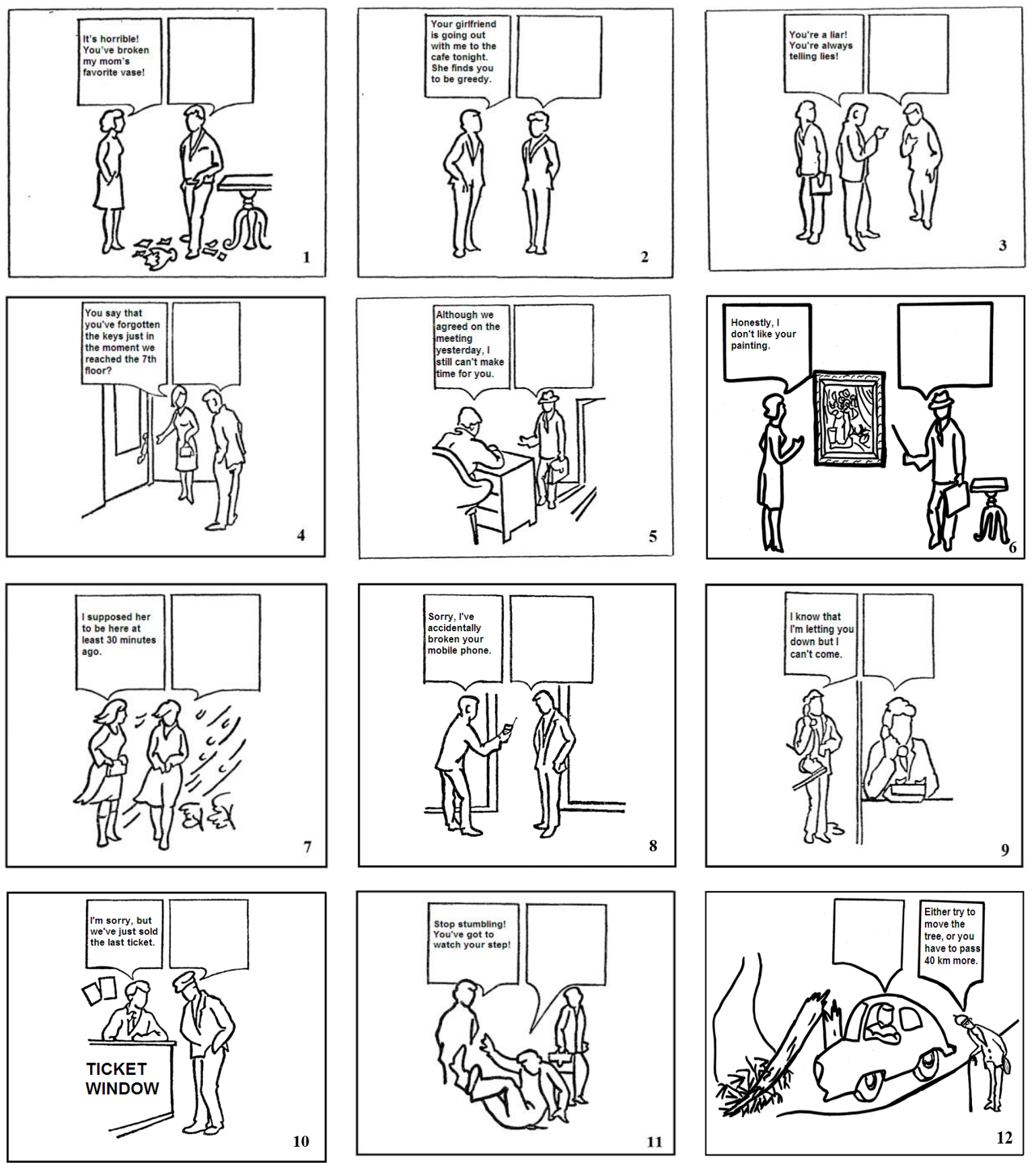

Fig.1. Drawings of a semi-project method for determining the degree of formation of assertive behaviour.

In the original method the situations, represented in the text are divided into two main groups: situations of "obstacles", situations of "accusation". It is important to specify the types of frustrating situations, which the adolescents may face in real life, according to the categories of juvenile convicts. It gives an opportunity to determine the convicts' reactions regarding the specific situations.

In the modified version of the method the represented situations are divided into four main blocks: "situations of obstacles", "situations of fair critique", "situations of unfair critique", "provocative situations".

We have structured all the images presented above into the certain blocks that reflect the peculiarities of human reaction according to the content of the frustrating situation.

"Situations of obstacles" determine the person's reaction while facing the inability to achieve the desired or complications in meeting its needs. We also refer here the situations in which the plans of a person are violated, and the circumstances force it to make efforts to achieve the goal. For example: "I'm sorry, but we've just sold the last ticket".

"Situations of fair critique" determine the person's reaction for just comments and dissatisfaction with its behaviour expressed by others. For example: "You say that 
you've forgotten the keys just in the moment we reached the 7th floor?".

"Situations of unfair critique" determine the person's reaction to insults and unfair valuation. It happens when the society unfairly reproaches, insults and negatively evaluates the person and its actions, but in reality this person does not deserve such an assessment.

For example: "Stop stumbling! You've got to watch your step!".

"Provocative situations" determine the person's reaction to the statements that are intentionally aimed at bringing this person out of balance. This is the situation when the person for some reason does not adhere to the promise or when an unfair accusation is present.

For example: "I know that I'm letting you down but I can't come", "Although we agreed on the meeting yesterday, I still can't make time for you".

The drawings represented in the modified method have got a certain sequence. The situations of fair and unfair critique are put on the first place in order to make the convict involved to the work and to attract their interest with the given tasks. The next types of situations are given by turns according to their content.

Let's consider the method modification by the "obstacle" block, which includes five drawings. The details of picture № 8 were changed in order to bring the situation closer to the actual events that are relevant to the juvenile convicts' age. For example, the original image represents two people. One of them gives a torn newspaper to another and says: "Here is your newspaper. I'm sorry that the child has ripped it up". The torn newspaper is not relevant at present, so the situation does not carry the given semantic load. In the modified method the same picture represents the same people, but the newspaper is replaced by a mobile phone (Fig. 2). The broken mobile phone is more significant for teenagers than a torn newspaper.

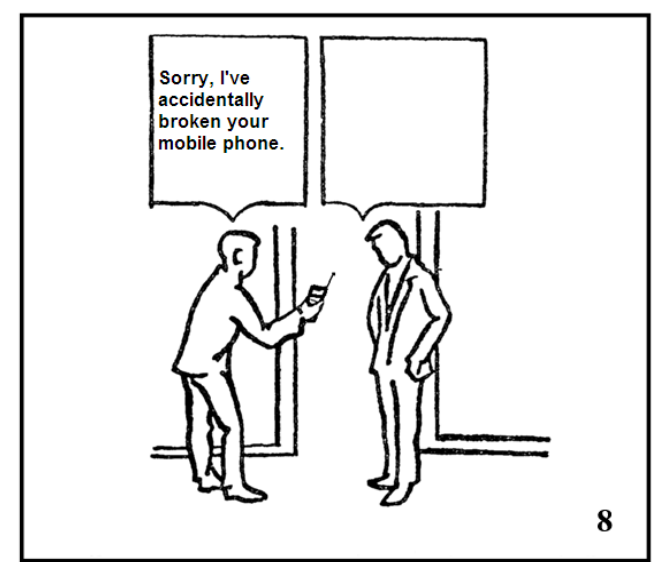

Fig.2. Picture № 8 of a semi-project method for determining the degree of formation of assertive behaviour.

The details of picture № 10 were changed in order to describe the situation close to the actual events juvenile convicts may face after their release. For example, the original image represents the situation in the store, where the cashier replies to the buyer: "I'm sorry, but we've just sold the last copy". In real life, this situation in a bookstore is not significant for adolescents. In the modified method the same picture represents the same people, but the situation takes place in the ticket office, where we can see the inscription "I'm sorry, but we've just sold the last ticket" (Fig. 3).

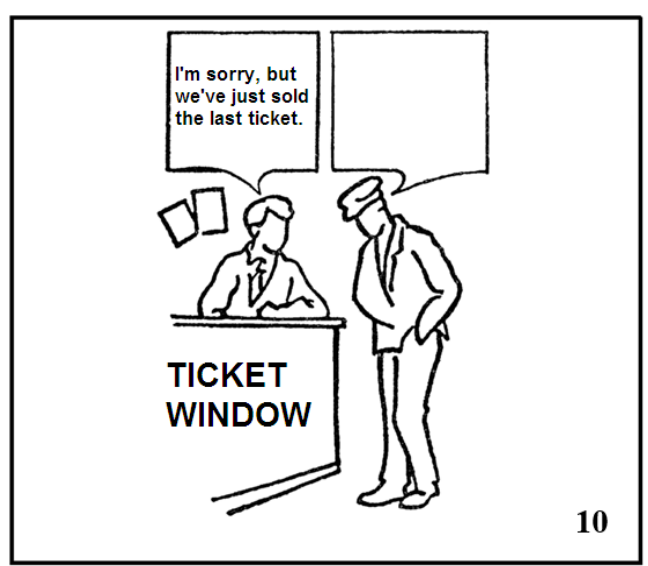

Fig.3. Picture № 10 of a semi-project method for determining the degree of formation of assertive behaviour.

The modified method was supplemented with two new drawings that reflect the situations of the "obstacle". Picture № 6 (Fig. 4) represents two people. One of them is showing a picture with the pointer, the other person says: "Honestly, I don't like your painting". This situation describes the obstacle for maintaining the positive "I" image.

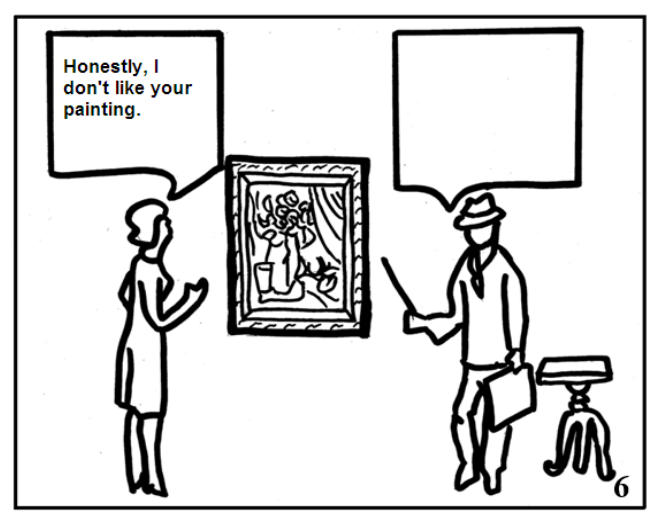

Fig.4. Picture № 6 of a semi-project method for determining the degree of formation of assertive behaviour.

Picture № 12 (Fig. 5) depicts the situation of the "obstacle" on the road, which is blocked with a broken tree. The man on the roadside says to the car driver: "Either try to move the tree, or pass by $40 \mathrm{~km}$ more".

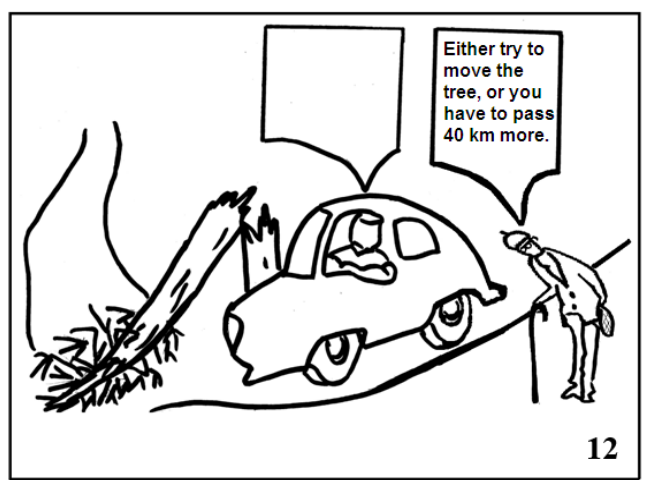

Fig.5. Picture № 12 of a semi-project method for determining the degree of formation of assertive behaviour.

Let's consider the method modification by the "fair critique" block, which includes two drawings. Image № 1 
corresponds to the original. The original text of picture № 4 "You seem to have lost your keys on purpose" was changed to "You say that you've forgotten the keys just in the moment we reached the 7th floor?" in order to make the juvenile convicts imagine the situation and feel emotions of the main hero.

Let's consider the method modification by the block "unfair critique", which includes two drawings. The original text of picture № 2 "Your girlfriend invited me to dance tonight. She said you wouldn't not come." was changed to "Your girlfriend is going out with me to the cafe tonight. She finds you greedy." in order to enhance the emotional load of the picture. The original text of picture № 11 "Are you okay?" was changed to "Why are you stumbling! Watch your feet!" in order to reflect the content of unfair critique.

Let's consider the method modification by the block "provocative behaviour", which includes three drawings. Pictures №5 and №9 correspond to the original. The original text of picture № 3 "You are a liar! You know that!" was changed to "You're a liar! You're constantly lying!" in order to enhance the emotional load of the picture and reflect the situation of provocative behaviour.

The original text of picture № 7 was "I supposed her to be here at least 10 minutes ago". By extending the waiting time we changed it to "I supposed her to be here at least 30 minutes ago".

Here is a short instruction to the method described above: "Look at this picture. Here are two people depicted. The words of the first person are written in a square field. How do you think another person replies him?".

Right after the given instruction, the researcher shows the drawings to the studied participants one by one. The experimenter reads the phrases from the drawigns, transmitting a clear intonation in accordance with the frustrating situation. The adolescents are asked to respond verbally. Each answer is being recorded or noted by the experimenter.

The main point in processing the results of the method was that all responses were divided into three types of behaviour in a frustration situation. This is due to the fact that the actual behaviour of adolescents is not only determined by their feelings but also mediated by social skills. Taking into account the juveniles reaction to frustrating situations, we have identified the types of behaviour strategies in accordance with the parameters of assertiveness: assertive, non-assertive (self-defense), aggressive. In the original method the assertive strategy of behaviour corresponds to an intropunitive response to a frustrating situation with the fixation on meeting the needs. The answer of the study participant is aimed at solving the problem. He takes the blame or assumes the responsibility for correcting this situation. In accordance with the assertive strategy of behaviour the person shows respect for the rights of other people.

This strategy is a correct emotional response to the frustrating situation. Non-assertive strategy of behaviour is an impunitive response with the fixation on selfdefense. The main role in the response of the convict is played by the protection of himself, his "I". The frustrating situation is considered as something that can be corrected all by itself just in course of time. An adolescent with non-assertive behaviour in solving his or her prob- lems relies on the actions of another person in order to get the desired without any efforts. In this case he resorts to manipulative behaviour not saying directly what he really wants to say [2].

The aggressive strategy of behaviour corresponds to an extrapunitive response with the fixation on self-defense or on an obstacle. The reaction is directed to the environment in the form of underlining the guilt of someone else, in the form of condemnation of the external cause of frustration or simply obliges another person to solve the situation. Negative emotionally colored responses, threats, indecent expressions are an obvious manifestation of aggression. The qualitative analysis of responses shown above was transferred into quantitative indicators. In particular, the strict correspondence of the phrase to the given parameters of assertive behaviour was evaluated in two points. However, it turned out that uncertain behaviour, the one that includes elements of each of the options, is possible. For example, in the situation "Sorry, I've accidentally broken your mobile phone" the juvenile convict replies "You must repair it". This answer means the presence of both: the aggressive behaviour and the way out of the situation. Hence, 0.5 points for the assertive strategy of behaviour may be added to the aggressiveness. We determined the amount of points for each type of reaction to frustrating situations in accordance with the parameters of assertive behaviour. It became clear that besides the three strategies of behaviour in frustrating situation, juvenile convicts reveal two more strategies: unformed and controversial behaviour. The adolescents with controversial behaviour strive to insist on their own on the one hand, but they often are not confident in their abilities. It causes negative feeling (because of an internal conflict), which can manifest itself in aggressive behaviour. In case none of the reactions to frustration prevails (they manifest evenly regardless of the situation) one can suppose that the convicted person has an unformed behaviour in a frustrating situation. Thus, the research shows that there are five main types of reaction to the frustration, expressed by juvenile convicts: assertive behaviour, unformed behaviour, controversial behaviour, non-assertive behaviour, aggressive behaviour. Here are the results in which the types of behaviour of juvenile convicts in a frustrating situation are presented in comparison with the pupils of general education schools (Fig. 6).

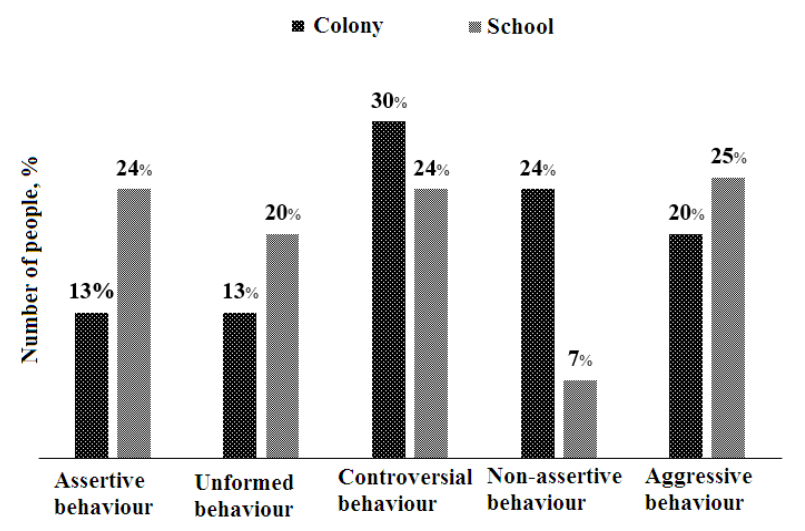

Fig.6. Types of behaviour of juvenile convicts in a frustrating situation in comparison with the pupils of general education school 
As you can see from the chart, the juvenile convicts detect considerably less strategies for assertive behaviour in comparison with the children of school age. The schoolchildren behave aggressively more often than the juvenile convicts do. At the same time, the level of non-assertive behaviour among the schoolchildren is more than three times lower.

Conclusions. An important component of the resocialization of juvenile convicts is the formation of social skills, in particular the reactions of juvenile convicts to various frustrating situations that may occur in their lives. It gives an opportunity to determine the sociopsychological readiness of the adolescent to release and to prevent recurrence. Timely detection of the tendency to unconstructive reactions of juveniles in frustrating situations is the basis of correction of their behaviour in conditions of educational colonies.

Assertiveness is a person's awareness of the right to achieve what he or she desires; the ability to express thoughts and feelings directly - both positive and nega- tive, but in a way not to violate the rights of other people. Assertiveness is precisely the condition for constructive behaviour in frustrating situations.

The modified method of S. Rosenzweig, allowed us to structure the incentive material according to the content of frustrating situations by the following blocks: "situations of obstacles", "situations of fair critique", "situations of unfair critique", "provocative situations".

While analyzing the variants of juveniles' reaction to frustrating situations, we have identified the types of behaviour strategies in accordance with the parameters of assertiveness: assertive, non-assertive, aggressive, contradictory, unformed.

The results of the analysis show that the juvenile convicts detect considerably less strategies for assertive behaviour in comparison with the children of school age. The schoolchildren behave aggressively more often than the juvenile convicts do. At the same time, the level of non-assertive behaviour among the schoolchildren is more than three times lower.

\section{ЛИТЕРАТУРА}

1. Журавель Т.В. Підготовка до звільнення осіб, які відбувають покарання у виді обмеження або позбавлення волі на певний строк, у тому числі неповнолітніх: методичний посібник / Т.В. Журавель, Ю.В. Пилипас та інші // К.: "Bepco-04". - 2012. - 168 c.

2. Каппони, В. Как делать все по-своему или ассертивность в жизнь /В. Каппони, Т. Новак. -СПб.: Питер, 1995. -186 c.

3. Максимова Н.Ю. Психологія девіантної поведінки Н.Ю. Максимова // Навчальний посібник для студентів вищих навчальних закладів. - К.: Либідь. - 2011. - 520 с.

4. Недибалюк О.С. Комунікативна компетентність неповнолітніх засуджених як складова соціально-психологічної готовності до ресоціалізації / О.С. Недибалюк // Збірник матеріалів науково-теоретичної конференції „Пенітенціарна теорія та практика України очима молодих науковців”, 17 квітня 2015 р., м. Київ / відп. ред. Є.Ю. Бараш, С.Г. Стеценко. - К.: Ін-т крим.-викон. служби. - 2015. C. $167-169$

5. Сборник психологических тестов. Часть III: Пособие / Сост. Е.Е.Миронова - Мн.: Женский институт ЭНВИЛА, 2006. $-120 \mathrm{c}$.

\section{REFERENCES}

1. Zhuravel T.V. Preparation for the release of persons serving a sentence in the form of restraint or imprisonment for a certain period, including juveniles: a methodical manual / T.V. Zhuravel, Yu.V. Pilipas et al. // K.: "Verso-04". - 2012. $-168 \mathrm{c}$.

2. Kapponi V. How to do everything in own way or assertiveness in life /V. Kapponi, T. Novak. -SPb.: Piter, 1995. -186 p.

3. Maksymova N.Yu. Psychology of Deviant Behaviour / N.Yu. Maksymova // Educational manual for students of higher educational institutions. - K.: Lybid. - 2011. - 520 c.

4. Nedybaliuk O.S. Communicative competence of juvenile convicts as a component of socio-psychological readiness for resocialization / O.S. Nedybaliuk // Proceedings of the scientific-theoretical conference "Penitentiary theory and practice of Ukraine by the eyes of young scientists", April 17th, 2015, Kyiv / Resp. edit. E.Yu. Barash, S.G. Stecenko. - K.: Institute of Criminal Execution Service. - 2015. - C. 167-169.

5. Collection of psychological tests. Part III: A handbook / Redactor E.E. Mironova - Mn.: Women's Institute of ENVILA. $-2006 .-120 \mathrm{c}$. 